\title{
Védett és adventív növények állományfelmérése a budapesti Széchenyi-hegyen
}

\author{
NAGY Károly Menyhért és MALATINSZKY Ákos \\ Szent István Egyetem, Természetvédelmi és Tájgazdálkodási Intézet, Természetvédelmi \\ és Tájökológiai Tanszék, 2103 Gödöllö, Páter K.u. 1.; malatinszky.akos@mkk.szie.hu \\ Elfogadva: 2019. szeptember 2.
}

\begin{abstract}
Kulcsszavak: Budai-hegység, flóra, idegenhonos növények, sztyepprét, védett növényfaj.
Összefoglalás: A lakóövezetekkel körülvett és jelentős turistaforgalomnak kitett budapesti Széchenyi-hegy természetvédelmi jelentősége és az értékeket veszélyeztető tényezők sokasága szükségessé teszi a területen előforduló védett növényfajok állományainak felmérését. 33 védett és 1 fokozottan védett növényfaj közel tizenkétezer állományát találtuk meg, harminckétezer virágzó hajtással. Jogszabályban meghatározott természetvédelmi értékük alsó becslés alapján is meghaladja a százmillió forintot. A különféle pontusi-pannon, keleti és szubmediterrán flóraelemek vannak túlsúlyban, igazolva a szubmediterrán klímahatás érvényesülését.
\end{abstract}

\section{Bevezetés}

Budapest flórájának vizsgálata már a 18. században elkezdődött. Az eddig megjelent közlések azonban terjedelmükből fakadóan kevésbé alkalmasak egy kisebb terület részletes tárgyalására. Emellett a változások vizsgálata is elengedhetetlenné teszi a védett fajok állományainak monitorozását a káros tendenciák felismeréséhez és szükség esetén a beavatkozáshoz. Célunk a föváros egy kis szeletének, a lakott területekkel körülvett, sokak által látogatott, természeti értékekben bővelkedő, mégis kevéssé kutatott Széchenyi-hegy védett és adventív növényfajainak feltérképezése és állományaik felmérése.

Budapest növényvilágának vizsgálatával számos kutató foglalkozott az elmúlt évszázadok során. Az első jelentősebb felmérések a török megszállás következtében a hasonló európai törekvésekhez képest kissé megkésve kezdődtek meg hazánkban. A Buda várát ostromló seregben tevékenykedő Luigi Marsigli hadmérnök számos természetrajzi megfigyelést végzett a Dunára és környékére vonatkozóan, és eredményeit 1726-ban adta ki Danubius Pannonico-mysicus címmel. Ebben elsőként kapunk átfogó képet Magyarország növény- és állatvilágáról, amiben kiemelt szerep jut Budának és környékének (PÉNZES 1942).

A következő jelentősebb természetrajzi kutatások a 18. század végén következtek, a Pázmány Péter tudományegyetem Budára, majd Pestre helyezését köve- 
tően. Hosszú időn keresztül ez volt a természetrajzi kutatások központja. Winterl József Jakab, az egyetem növénytan tanára és a Füvészkert igazgatója megkezdte Budapest flórájának rendszeres kutatását. Budapesti vizsgálatainak eredményét 1788-ban Index Horti Botanici Universitatis Hungaricae, quae Pestini est címmel kiadott füvészkerti katalógusban közli az érdekesebb fajok neveivel és képeivel együtt. Ez a munka azonban félbemaradt, és az akkor még ismeretlen fajokat sem írta le a tudomány számára, csak jelezte azok létezését (PÉNZEs 1942).

Winterl utóda, Kitaibel Pál már a teljes ország növénytani kutatását tüzte ki célul, aminek következményeként a mai Budapest kiemelt vizsgálata helyi jelentőségű üggyé zsugorodott. A főváros első összefoglaló flóraművének megírására később Sadler József vállalkozott. Bár az egész országot beutazta, felismerte, hogy a főváros flórája számos ritka fajjal rendelkezik és változatos élőhelyi adottságai következtében kialakult fajgazdagsága miatt is kiemelt figyelmet érdemel. Elsőként egyetemi tanársegédként 1818-ban adta ki a Pest és Buda körül található növények betűsoros jegyzékét. Ebben 1167 növény nevét, élőhelyét és virágzási idejét adta meg. Ezt követően 1825-ben és 1826-ban jelent meg Flora Comitatus Pestiensis címü kétkötetes flóraműve, ami már az egész megyére kiterjedt, és határozóként is funkcionált. Ebben a fajok száma 1377-re bővült, ami az 1840-ben kiadott második kiadásban 1429-re emelkedett. A korábban említett művek magyar nyelvủ átdolgozását Gönczy Pál végezte el, akinek műve szélesebb kör számára tette elérhetővé Budapest és környéke flórájának megismerését. Műve 1864-ben jelent meg Pest megye és tájéka viránya címmel (PÉNZEs 1942).

A kor szemléletének megfelelően Anton Kerner botanikus vizsgálatai már kiterjedtek a növényföldrajzi vonatkozásokra is. Bár ő maga főleg országos kutatásokat végzett, a budai flóra tanulmányozásába az ő munkássága nyomán jutottak el a növényföldrajzi szempontok, és többek között Borbás Vince egyetemi tanár is nagy hasznát vette műveinek. Borbás 1879-ben erre támaszkodva írta meg a Budapest és környéke természetrajzi, orvosi és kőzmívelődési leírása című megyei monográfia növényzettel foglalkozó részét Budapestnek és környékének növényzete címmel. Ebben 170 oldalon keresztül ismerteti a növényfajokat, és mindvégig érvényesíti a növényföldrajzi szempontokat is, jellemezve az adott élőhelyek növénytársulásait, és földrajzi elterjedés szerinti fajcsoportokat különböztetve meg. Már ebben kiemeli azt a megfigyelését, hogy a fővárosi flóra jelentősen különbözik a közép-európai növényzettől a déli és keleti flóraelemek jelenléte miatt. A Széchenyi-hegyről említi például az Anthericum liliago, Amygdalus nana, Coronilla coronata, Iris pumila és a Lathyrus pallescens elöfordulását. Szintén figyelmet fordított a növények elterjedése és az antropogén hatások közötti összefüggések vizsgálatára. Bár a kutatások elsősorban a virágos növényekre koncentráltak, az élőhelyeket is tartalmazó fajlista jelentősen bővebb lett a korábbi műveknél, ugyanis elsőként tárgyal moszatokat, gombákat és zuzmó- 
kat is, amiben Hazslinszky Frigyes volt segítségére. Munkájában 1562 fajt, 403 eltérő alakot és 72 hibridet dokumentált. A korra jellemzően igen egyenetlen az egyes régiók florisztikai feltártsága, illetve meglehetősen nagy és természetföldrajzi szempontból eltérő területeket tárgyal együtt, ami a mü hiányosságának tekinthető (PÉNZEs 1942, SomLYAY 2009).

Az 1930-as évektől kezdődően Zólyomi Bálint is publikált több, Budaihegységre vonatkozó dolgozatot. Ezek föként történeti növényföldrajzi és cönológiai munkák voltak. Műveinek egyik legfontosabb eredménye a közép-dunai flóraválasztóról alkotott elképzelés volt. A fentiek mellett még számos kutató (pl. Istvánffy Gyula, Moesz Gusztáv, Szepesfalvy János) foglalkozott az addig kevésbé ismert virágtalan növényekkel is (PÉNZES 1942, SOMLYAY 2009).

$\mathrm{Az}$ addig napvilágot látott flóraművek inkább csak egy szük réteg számára íródtak, miközben egyre nagyobb igény jelentkezett egy könnyen használható és közérthető leírásra Budapest környékének flórájáról. Ezt a hiányt Pénzes Antal 1942-ben megjelent Budapest élővilága címủ könyve pótolta először, ami már foglalkozott az addigra egyre gyakrabban felmerülő ökológiai kérdésekkel és az élőlények életmódjának ismertetésével is. Egy újabb átfogó kutatásra már csak azért is nagy szükség volt, mert a Borbás óta eltelt bő fél évszázad alatt a főváros népessége több mint háromszorosára növekedett (KözPonTi STATISZTIKAI HivaTAL 2011). Ez természetesen együtt járt a táj átalakításának felgyorsulásával, a korábbi természetközeli területek beépítésével és a művelési ágak megváltozásával.

Hegedüs Ábel 1974 és 1993 között gyüjtött adatokat Budapest és környékének flórájáról, amit Budapest jelenlegi virágos flórája címü művében adott ki (HEgEDÜs 2002). Az eredményeket Sadler József és Borbás Vince adataival vetette össze, a növényzetben végbement változások nyomon követése érdekében. Munkájában 1417 növényfajt gyüjtött össze lelőhelyeik megadásával.

Az utóbbi években számos publikáció jelent meg a Budai-hegység kisebbnagyobb szeletének növényzetével kapcsolatban, amik között jelentősebb Somlyay Lajos munkássága (SOMLyay 2009, 2011, SomLyay et al. 2016). Somlyay évekig tanulmányozta a Budai-hegység növényzetét terepi, irodalmi és herbáriumi kutatások során, ami alapján több növényföldrajzilag jelentős taxon elemzését és elterjedésének vizsgálatát végezte el. A környező területek (pl. Szent János Kórház, Szépjuhászné környéke) páfrányaira vonatkozóan közöltek adatokat Tamás és munkatársai (TAMÁs et al. 2017a). A közelmúltban megjelent cikkünkben (NAGy és MaLATinsz Ky 2019) kimutattuk, hogy a Széchenyi-hegyen a védett növényfajok állományainak sűrűsége és példányszáma a legrégebb óta gyepként jelölt 2,4 hektáros, déli lejtésủ folton a legnagyobb.

A Budai-hegység ritkaságokban és endemikus fajokban gazdag. Ez a faji szintủ diverzitás rendszerint az élőhelyek sokféleségének köszönhető, ami a biodiverzitás táji szintű kifejeződéseként is értelmezhető (Hou és WALZ 2016). 
Már PÉnZEs (1942) is kiemelte a Farkas-völgy és a Széchenyi-hegy természetvédelmi jelentőségét. Ennek a területnek a védelmére azonban még több mint három évtizedet kellett várni, miközben mint beépítendő terület szerepelt a fóváros rendezési tervében. 1978-ban létrehozták a Budapestet északnyugatról övező Budai Tájvédelmi Körzetet. Később az európai uniós csatlakozással kijelölésre kerültek az európai szintű természetvédelmi oltalomra érdemes területek, amibe a tájvédelmi körzet nagy része, és számos, korábban hazai jogszabállyal nem védett terület is belekerült. A közösségi jelentőségű fajok és élőhelytípusok védelme és elterjedésük, kiterjedésük, funkciójuk és struktúrájuk monitorozása kötelező az EU tagállamokban (MöcKel 2017, ElLwANGER et al. 2018), különösen annak fényében, hogy bár a védett természeti területek kiterjedése világviszonylatban folyamatosan növekszik, Európában döntő részük kis $\left(<10 \mathrm{~km}^{2}\right)$ kiterjedésü (BAlogh et al. 2016, Bognár et al. 2016, PeChANec et al. 2018).

\section{Anyag és módszer}

A Széchenyi-hegy (472 m) a Budai-hegység tagja. Uralkodó kőzete a felsőtriász dolomit, kisebb részben mészkő (Havas 1976). A pliocén végén édesvízi mészkő rakódott le 10-12 méter vastagságban. A terület éghajlata mérsékelten hüvös, mérsékelten száraz; a csapadék eloszlása alapján szubmediterrán jellegű. A napsütéses órák száma évi 1930 óra. A hegy tetejének klímája hidegebb a fővárosi átlaghoz képest. Az évi középhőmérséklet $8,7^{\circ} \mathrm{C}$, a januári $-2,5^{\circ} \mathrm{C}$, a júniusi pedig $19,5-20^{\circ} \mathrm{C}$. Gyakori jelenség a téli hőmérsékleti inverzió. Ilyenkor akár $10^{\circ} \mathrm{C}$-kal is hidegebb hőmérséklet mérhető a fagyzugos völgyekben a magasabban fekvő területekhez képest. A Széchenyi-hegyi meteorológiai állomás mérései szerint az átlagos éves csapadékmennyiség 650-700 mm, a legtöbb nyár elején hullik, a legkevesebb tél végén. Átlagosan 50-55 napig megmaradhat a hótakaró. A Széchenyi-hegyen nem található felszíni forrás. A mészkő- és dolomitfelszíneken rendzina talaj jellemző (DövÉNYi 2010). A terület a pannon vegetációrégió része (FEKETE et al. 2017).

A vizsgált terület a Széchenyi-hegy központi, délies kitettségű lejtőin helyezkedik el, határai a lakóövezet, a Gyermekvasút végállomása, egy katonai bázis, a televízióadó és a Nemzeti Közszolgálati Egyetem épületei, valamint délen a János Zsigmond utca (1. és 2. ábra). A területet rendszeresen - 2015-ben és 2016-ban a vegetációs időszakban 2-4 heti gyakorisággal - bejártuk. A központi elhelyezkedésű gyep kiterjedése megközelítőleg 8,5 hektár. A gyepek körül a műholdképek alapján szintén kijelöltünk egy - a helyszínen is könnyen lehatárolható - körülbelül 77,5 hektár kiterjedésű cserjés, erdős területet (2. ábra). A védett növényfajok előfordulásait GPS koordinátával vettük fel, míg a nem védett fajokról listát készítettünk. A taxonok megnevezésekor KIRÁLY 


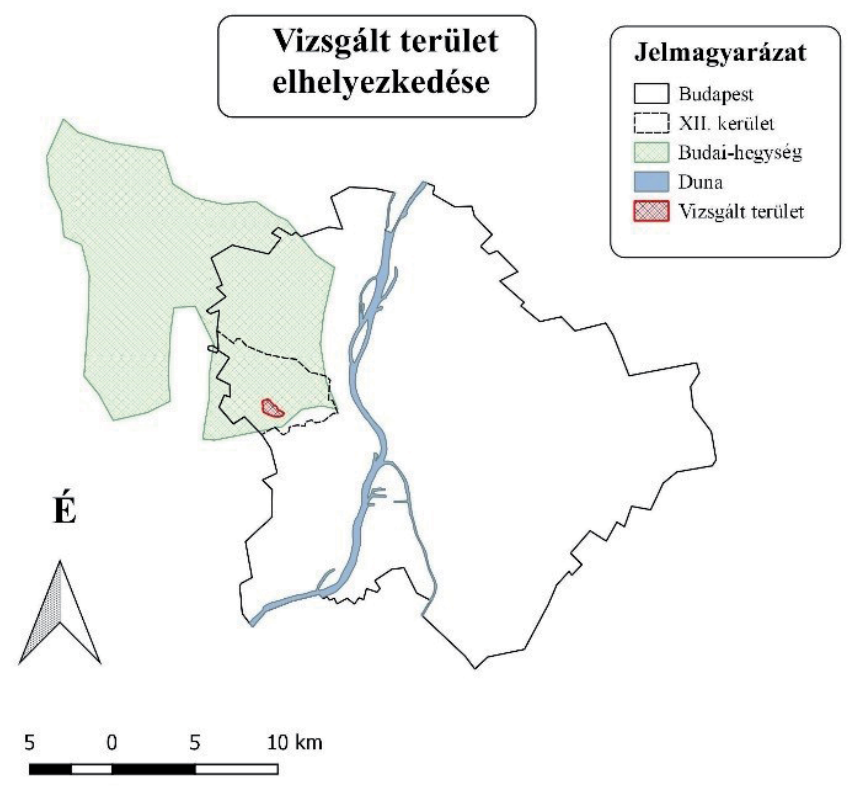

1. ábra. A vizsgált terület elhelyezkedése.

Fig. 1. Location of the studied area.

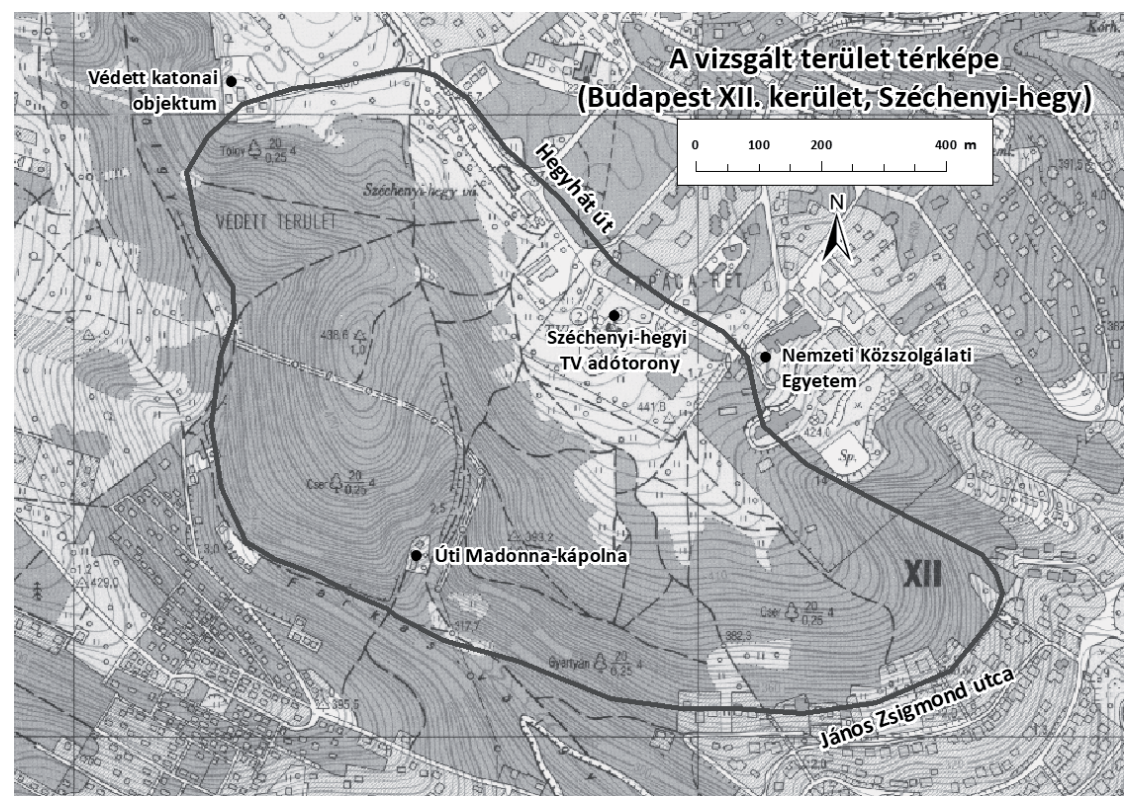

2. ábra. A vizsgált terület részletes térképe a fó tájékozódási pontokkal.

Fig. 2. A detailed map of the studied area. 
(2009) munkáját követjük. A flóraelem-típusok meghatározásánál Simon et al. (2000) táblázatát vettük alapul.

Sok esetben nehézséget okozott a vizsgálat során az egyes egyedek elkülönítése, aminek több oka is volt. Számos faj sarjtelepeket hoz létre (pl. Iris pumila, Lathyrus pallescens), ezek pontos elhatárolása nehéz, vagy nem lehetséges. Ennek feloldására két értéket rögzítettünk minden feljegyzett taxon esetében: a virágzó hajtások és az állományfoltok számát. Ez utóbbi pontos meghatározása sok esetben nehézségekbe ütközött - a gyakorlatban azokat a töveket számoltuk egy foltnak, amik láthatóan és nagy valószínüséggel egy telepet alkothattak. Sok esetben akkor is ezt a módszert alkalmaztuk, ha bár nem polikormonképző fajról volt szó, de foltokban nagyon sürün helyezkedtek el a tövek (pl. Polygala major), és ezért nehéz volt elkülöníteni az egyes egyedeket. Az előzőhöz hasonló problémát okoznak a földfelszínen indákkal kúszó vagy elterülő növények (pl. Convolvulus cantabrica), illetve a tömegesen virágzó fajok (pl. Allium sphaerocephalon). Ezek elkülönítése fizikailag lehetséges ugyan, azonban a pontos számlálás aránytalanul sok időt venne igénybe. Ezért egy kisebb mintaterületen összeszámolva a vizsgált fajok egyedszámát, a teljes terület és a mintaterület méretének arányából számítottunk ki egy közelítő értéket a teljes egyedszámra vonatkozóan.

A kutatási területen található védett növények nagy száma miatt az összes példány helyének egyedi rögzítése nem volt lehetséges. Emiatt az egyes koordináták nem egyetlen elkülöníthető egyed adatait jelölik, hanem az adott középpontú és méretủ kvadrátban található összes példány adatait. A terepi mintavételezés hatékonyságának érdekében változó kvadrátmérettel dolgoztunk. Amíg ugyanis egyes ritkább fajok akár egyesével is könnyen rögzíthetők voltak, addig a tömegesen elöfordulóknál ez több okból sem volt kivitelezhető. Először is a GPS készülék nem volt alkalmas arra, hogy olyan pontossággal dolgozzon, ami lehetővé tenné a mindössze centiméteres távolságban lévő egyedek elkülönítését. Másodszor pedig az esetenként néhány négyzetméteren található több száz egyed rögzítése aránytalanul sok időt igényelt volna. Ezért az adott faj gyakoriságától függő kvadrátméretet használtunk az alábbi értékekkel:

- nagyon ritka fajok: $1 \mathrm{~m} \times 1 \mathrm{~m}$-es kvadrát;

- ritka fajok: $2 \mathrm{~m} \times 2 \mathrm{~m}$-es kvadrát;

- közepes gyakoriságú fajok: $3 \mathrm{~m} \times 3 \mathrm{~m}$-es kvadrát;

- gyakori fajok: $4 \mathrm{~m} \times 4 \mathrm{~m}$-es kvadrát;

- nagyon gyakori fajok: $5 \mathrm{~m} \times 5 \mathrm{~m}$-es kvadrát.

Bár az egyes fajok gyakoriságát a helyszínen becsültük, az adatok utólagos feldolgozása során arra az általánosításra lehet jutni, hogy nagyon ritka fajok közé a körülbelül 50-es állományfolt-szám alattiak tartoztak, a ritkák az 51-100 között lévők, közepesnek a 101-250 közötti, gyakorinak a 251-500 közöttiek, 
míg nagyon gyakorinak azon fajok tekinthetők, amik 500 fölötti állományfolttal rendelkeztek a vizsgált területen.

Az egyazon fajon belüli elnyúlt virágzás nehézséget okozott, ugyanis két eltérő terepbejárás alkalmával az azonos helyen talált virágzó egyedek megkülönböztetésére a helyszínen nem volt lehetőség. A rövid virágzási periódussal rendelkező fajoknál (pl. Iris pumila) ez nem jelentett problémát, ugyanis a bejárások gyakorisága nagy valószínűséggel kizárta, hogy ugyanazt a példányt kétszer rögzítsük. A hosszabb ideig virágzó fajoknál (pl. Dictamnus albus) azonban a két külön időszakban elvégzett számlálás esetén előfordulhatott, hogy ugyanazt az egyedet többször feljegyeztük. Ezért minden alkalommal rögzítettük a virágzó példányokat, és utólag szürtük ki a nagy valószínűséggel azonos egyedeket. Ezt az egyes pontok közötti távolság alapján végeztük, amihez a bemutatott fajfüggő kvadrátméretet használtuk. A rögzített pontok nagy száma miatt ennek manuális elvégzése túl sok időt vett volna igénybe, ezért automatizáltuk a pontok közötti távolság kiszámítását. Az így kapott adott távolságon belüli pontpárok esetén azzal a feltételezéssel éltünk, hogy azok nagy valószínűséggel azonos példányok. Ezeknél a pontoknál a két külön időpontban rögzített egyedszám értékek közül csak a nagyobbat őriztük meg. Abban az esetben, ha egy ponthoz (A) egy másik vizsgálat során több pont is a megadott távolságon belül helyezkedett el (B1, B2, ... Bx), akkor ez utóbbiak értékének összegét hasonlítottuk az A ponthoz. Ritkán ennél bonyolultabb kapcsolatrendszer is kialakult az egyes pontok között, amihez felrajzolva egy megfelelő gráfot, a fentihez hasonló módon elvégeztük az adatok szürését. $A$ botanikai adatok jelentőségének megítéléséhez Bajor (2009), Bartha et al. (2015), Borbás (1879), Molnár (2007), PÉnzes (1942, 1956), Somlyay (2009, 2011), Somlyay és Pif Kó (2002), Somlyay et al. 2016) és Szollát (2006) munkái voltak segítségünkre.

\section{Eredmények és értékelésük}

A vizsgált területen 33 védett és 1 fokozottan védett növényfaj állományait mértük fel, adataikat az 1. táblázat tartalmazza. Mivel a pontos egyedszámok meghatározása a vizsgálati módszerek részletezésénél leírt okok miatt nem minden esetben lehetséges, ezért a természetvédelmi értékek kiszámításánál az állományfoltok számát használtuk fel, ami így alsó becslésnek felel meg. A területen található védett növényfajok természetvédelmi értéke így is meghaladja a 100 millió forintot, aminek döntő hányada a mindössze 8,5 hektáros gyepterületen található.

A fellelt védett növényfajok legtöbbjének volt már adata a hegyről (pl. Borbás, Sadler, Somlyay és Pifkó adatközlései, Magyarország edényes növény- 
Nagy K. M., Malatinszky Á.

1. táblázat. A Széchenyi-hegyen észlelt védett növényfajok adatai.

Table 1. List of protected plant species observed on the Széchenyi Hill, Budapest. (1) scientific name; (2) nature conservation value in HUF according to the relevant legislation; (3) number of flowering shoots; (4) number of stands; (5) sum of nature conservation value.

\begin{tabular}{|c|c|c|c|c|}
\hline Tudományos név (1) & $\begin{array}{l}\text { Természetvédelmi } \\
\text { érték (13/2001 } \\
\text { KöM rendelet) (2) }\end{array}$ & $\begin{array}{c}\text { Virágzó } \\
\text { hajtások } \\
\text { száma (3) }\end{array}$ & $\begin{array}{l}\text { Állomány- } \\
\text { foltok } \\
\text { száma (4) }\end{array}$ & $\begin{array}{l}\text { Összes termé- } \\
\text { szetvédelmi } \\
\text { érték }(\mathrm{Ft})(5)\end{array}$ \\
\hline Aconitum vulparia & 5000 & 160 & 160 & 800000 \\
\hline Adonis vernalis & 5000 & 770 & 274 & 1370000 \\
\hline Allium sphaerocephalon & 5000 & 1699 & 609 & 3045000 \\
\hline Amygdalus nana & 10000 & 700 & 30 & 300000 \\
\hline Anemone sylvestris & 5000 & 44 & 15 & 75000 \\
\hline Aster amellus & 5000 & 123 & 40 & 200000 \\
\hline Asyneuma canescens & 5000 & 1891 & 220 & 1100000 \\
\hline Centaurea scabiosa subsp. sadleriana & 5000 & 9622 & 3280 & 16400000 \\
\hline Centaurea triumfettii & 5000 & 203 & 87 & 435000 \\
\hline Cephalanthera damasonium & 10000 & 33 & 27 & 270000 \\
\hline Convolvulus cantabrica & 5000 & 131 & 78 & 390000 \\
\hline Coronilla coronata & 5000 & 544 & 165 & 825000 \\
\hline Crepis nicaeensis & 5000 & 42 & 29 & 145000 \\
\hline Dictamnus albus & 5000 & 1901 & 1072 & 5360000 \\
\hline Erysimum odoratum & 5000 & 570 & 442 & 2210000 \\
\hline Inula oculus-christi & 5000 & 49 & 49 & 245000 \\
\hline Iris pumila & 5000 & 1943 & 903 & 4515000 \\
\hline Iris variegata & 5000 & 25 & 6 & 30000 \\
\hline Jurinea mollis & 5000 & 588 & 246 & 1230000 \\
\hline Lathyrus pallescens & 250000 & 452 & 163 & 40750000 \\
\hline Limodorum abortivum & 10000 & 140 & 91 & 910000 \\
\hline Linum flavum & 10000 & 22 & 12 & 120000 \\
\hline Linum tenuifolium & 5000 & 3122 & 327 & 1635000 \\
\hline Lychnis coronaria & 10000 & 2 & 2 & 20000 \\
\hline Orchis purpurea & 10000 & 28 & 28 & 280000 \\
\hline Phlomis tuberosa & 5000 & 27 & 21 & 105000 \\
\hline Polygala major & 5000 & 2090 & 495 & 2475000 \\
\hline Pulsatilla grandis & 10000 & 2557 & 846 & 8460000 \\
\hline Scorzonera purpurea & 5000 & 118 & 60 & 300000 \\
\hline Serratula radiata & 10000 & 151 & 78 & 780000 \\
\hline Silene bupleuroides & 10000 & 8 & 8 & 80000 \\
\hline Sorbus danubialis & 10000 & 9 & 8 & 80000 \\
\hline Sternbergia colchiciflora & 10000 & 50 & 50 & 500000 \\
\hline Vinca herbacea & 5000 & 2943 & 1952 & 9760000 \\
\hline Összesen & & 32757 & 11873 & 105200000 \\
\hline
\end{tabular}


fajainak elterjedési atlasza). Az adatok egy részének megerősítése önmagában is fontos, emellett a korábbi adatközlések tőszámot, állományméretet, pontos elhelyezkedést (a publikációk jellegéből adódóan) nem tüntettek fel. Az Anemone sylvestris-nek a friss flóraatlaszban (BARTHA et al. 2015) nem volt adata a Széchenyi-hegy kvadrátjából (7985.2); az általunk (is) rögzített állományhoz legközelebb a 7985.4 kvadrátban szerepelt. Azóta a második szerző adatközlése nyomán, Molnár et al. (2017) révén már bekerült az online adatbázisba.

Vizsgálataink során nem sikerült kimutatnunk néhány, a területről már leírt védett növényfajt. Közéjük tartozik a területen korábbi években általunk is észlelt Thlaspi jankae (SOMlyay 2009). A már BorBÁs (1879) által is említett Anthericum liliago helyett csak $A$. ramosum-ot találtunk, míg az általa szintén közölt Conringia austriaca az általunk szisztematikusan felvételezett területen kívül (északnyugati irányban) került szemünk elé. A Lilium martagon-t távolabbi erdőkben észleltük. A Sorbus graeca és az Astragalus vesicarius subsp. albidus PÉnzes (1942) által jelzett állományait nem találtuk meg. BorBÁs (1879) a Sváb-hegy fennsíkjáról, vagyis minden bizonnyal az általunk is kutatott területről jelezte az Anacamptis pyramidalis, a Dactylorhiza sambucina és az Orchis pallens előfordulását; ezek egyikét sem tudjuk megerősíteni.

Az Aconitum vulparia példányait egy közepes kiterjedésű összefüggő foltban sikerült megtalálnunk a hegy délkeleti lábánál. Stabil populációval rendelkezik, azonban veszélyeztető tényező a közeli erős beépítettség. A Cephalanthera damasonium néhány töves állományokban fordult elő a délies kitettségű árnyékosabb szegélyekben. Hasonló mennyiségben és gyakorisággal volt jelen az Orchis purpurea is, azonban az előzőnél árnyékosabb száraz tölgyesekben és bokorerdőkben. Délies kitettségü, napos szegélyekben néhány tő Sorbus danubialis volt jelen. Adonis vernalis a bokorerdők közötti tisztásokon él nagyobb mennyiségben, föként a délies fekvésü, bolygatatlan területeken. Az Anemone sylvestris-nek csak egy foltszerü állományát leltük meg egy árnyékosabb erdőszegélyben. Főleg az erdőssztyeppréteken található a Centaurea triumfettii nagyobb területen elszórtan, míg a Phlomis tuberosa-nak csak kisebb foltjára akadtunk rá egy délies fekvésű, napos, nyílt területen. A nyílt és a szegély jellegű területeken a száraz gyepekben szinte mindenütt megtalálható az Erysimum odoratum. A délies fekvésű, napos, bolygatatlan sztyepprétek egyik jellemző faja a Jurinea mollis.

Az összes feljegyzett védett növényfaj közül legnagyobb egyedszámmal a Centaurea scabiosa subsp. sadleriana rendelkezett, szinte minden gyepfoltban előfordul. A Dictamnus albus is szinte mindenütt megtalálható, főleg a szegélyzónákban, de a mészkedvelő tölgyesekben is számos helyen. A Linum tenuifolium elterjedése szűkebb területre korlátozódott, főleg a délies kitettségű, napos, bolygatatlan, köves lejtősztyeppeken volt jellemző. Az előzőhöz nagyon hasonló elterjedést mutat a Polygala major, ami némileg kisebb területeken, de általában 
tömegesen volt jelen. Az Amygdalus nana példányait viszonylag nagy egyedsürűséggel találtuk meg délies kitettségű, napos, száraz erdőszegélyben. Kissé nagyobb területen, de hasonlóan szigetszerủ elterjedéssel voltak megfigyelhetők az Aster amellus egyedei egy délies kitettségü száraz gyepfoltban. A Scorzonera purpurea föleg a sztyepprétek szegélyeiben volt jelen, viszonylag kis egyedszámmal, de nagyobb területen elszórva. A Lathyrus pallescens jelentős egyedszámmal fordul elö, néhány kisebb és két nagyobb összefüggő foltban. Minden esetben a zárt, magas füvű, sok pillangós virágú fajjal jellemezhető szegélyekben fordul elö, és akár több négyzetméteres sarjtelepeket is alkot. Hazánkban jelenleg a Széchenyi-hegyi állományon kívül csak a közeli Csillebércen (SOMLYAY és PıF Kó 2002), és nagyon kis (tízes nagyságrendü) egyedszámmal a gyöngyösi Sár-hegyen (Molnár 2007) található bizonyított előfordulása. Az Asyneuma canescens és a Serratula radiata elszórtan, kisebb-nagyobb foltokban él főleg a gyep-erdő szegélyterületeken. A Linum flavum-ot kis egyedszámmal sikerült kimutatnunk egy napos nyílt gyepfoltban. Szerencsére a Natura 2000 jelölőfajként is számon tartott Pulsatilla grandis még igen sok helyen fellelhetö, főként a délies kitettségü, napos, bolygatatlan lejtősztyeppeken. Az előbbihez nagyon hasonló előfordulási mintázattal rendelkezik az Iris pumila is, amit az egyik legnagyobb egyedszámmal sikerült kimutatnunk. Az I. variegata ezzel szemben csak néhány elszigetelt foltban élt az árnyékosabb erdőszegélyekben. Igen gyakorinak számított a tipikus erdőssztyepp elterjedésü Vinca herbacea.

Az Allium sphaerocephalon egyedei föként a plató helyzetben lévő napos sztyeppréteken fordultak elö. A sztyepprétek, bokorerdők egyik tipikus fajának, a Convolvulus cantabrica-nak azonban csak néhány, egymáshoz közeli, kis egyedszámú foltját észleltük, főként a félárnyékos szegélyzónákban. A mészkedvelő tölgyesek és bokorerdők néhány egymástól elkülönült kisebb foltjában él a Coronilla coronata. A Crepis nicaeensis a terület északi szegélyében fordul elö. A korábbi flórakutatások (pl. Sadler) adatai alapján a Budai-hegység ilyen élőhelyein még igen gyakori fajnak számított. Erdő aljában bukkantunk a Sternbergia colchiciflora állományára. A Limodorum abortivum-ot egy kisebb és egy meglepően nagy területen sikerült kimutatnunk a száraz tölgyesek félárnyékos foltjaiban. Ez utóbbi területen meglehetősen stabil állománnyal rendelkezik. Feltehetően azonos a Farkas-völgy megjelöléssel közölt adattal (SOMLYAY 2009, SoMLYAY és PIF Kó 2002, Somlyay et al. 2016). Az Inula oculus-christi-t néhány elszórt állományban találtuk meg.

Örvendetes tény, hogy az adventív elemek viszonylag alacsony faj- és egyedszámmal voltak jelen vizsgálataink idején a Széchenyi-hegyen. Összesen hat jövevényfajjal találkoztunk a terepi vizsgálatok során: Ailanthus altissima (6 virágzó hajtás / 6 állományfolt; a továbbiakban csak a számokat jelezzük), Conyza canadensis (1/1), Erigeron annuus (23/16), Mahonia aquifolium 
(108/108), Solidago canadensis (5/3), S. gigantea (1/1). A Taxus baccata is kis egyedszámú. Elsősorban az Ailanthus altissima jelenléte aggasztó, mert bár csak néhány töves állománnyal találkoztunk, már most is jól látszik az intenzív terjeszkedése, és mindemellett közismerten nehéz visszaszorítani. Legnagyobb példányszámban a Mahonia aquifolium fordul elö, ami feltehetően a közeli kertekből szabadult ki.

\section{Következtetések és javaslatok}

Az összegyüjtött harmincnégy védett (illetve fokozottan védett) faj több mint harminckétezer virágzó hajtásának adataiból belátható a terület nagy természetvédelmi értéke. A beépítések mellett off-road kerékpározók, a kijelölt turistautakról letérő kirándulók, vadkár (lásd TAMÁs et al. 2017b közelmúltbeli tanulmányát egy szomszédos területről), és egyéb károsító tényezők (pl. air-soft verseny, hajléktalantábor) fenyegetik. Bár a Budai Tájvédelmi Körzet részeként országos védelmet élvez, gyakorlati védelmét nehezíti többek között az is, hogy a fővárosban, forgalmas turistaút mentén terül el. 2003-ban elkezdődött a hegyi kerékpáros útvonalak kijelölése. A kijelölt útvonal a Széchenyi-hegy gyepjeit az aszfaltozott Hegyhát úton elkerüli, azonban a fogaskerekủvel érkező terepkerékpárosok sok esetben a gyepeket keresztező gyalogos turistautakat, illetve egyéb jelöletlen ösvényeket is használnak, nagy károkat okozva az érzékeny növény- és állatvilágban, továbbá növelve a talajveszteséget a hosszabb, illetve a meredekebb lejtőkön (CENTERI et al. 2015). A Crataegus monogyna térhódítása ugyan káros hatással van a fokozottan védett Lathyrus pallescens állományaira, azonban visszaszorítása jelentősen megnövelheti az emberi taposás okozta károkat. A bemutatott természeti értékek hosszú távú megőrzését sürgeti az ENSZ Fenntartható fejlődési céljai közül a 15. számú is, az alcélok között kiemelve a gyors és jelentős intézkedések megtételét a természetes élőhelyek romlásának mérséklésére, a biológiai sokféleség csökkenésének megállítására (JANCSOVSZKA 2016).

A védett növényfajok flóraelem-besorolásának vizsgálata alapján az is megállapítható, hogy a terület flórájában a különféle pontusi-pannon, keleti és szubmediterrán védett növényfajok vannak túlsúlyban, ami igazolja a szubmediterrán klímahatás érvényesülését a Széchenyi-hegyen (3. ábra).

HEGEDÜs (2002) vizsgálatainak eredményeként kapott fajlista alapján arra a megállapításra jutott, hogy az utóbbi 100-150 évben mintegy 341 növényfajjal lett szegényebb Budapest flórája, aminek nagy része az urbanizáció számlájára írható. Mindez tovább erősíti azt a tényt, hogy nagy szükség van a fajok rendszeres monitorozására a védelemre szoruló értékek meghatározásához. 


\section{Védett növényfajok flóraelem-megoszlása}

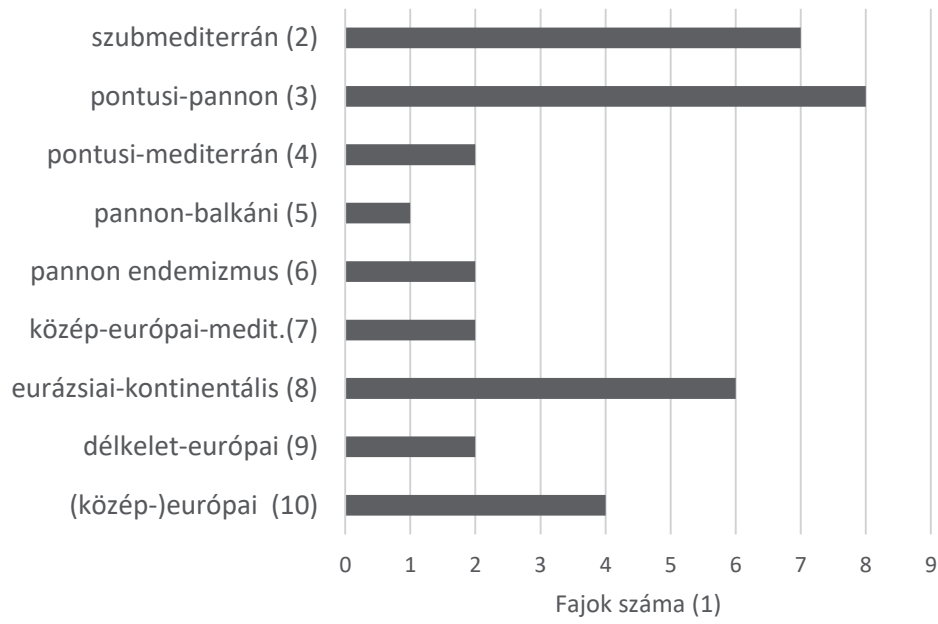

3. ábra. Flóraelemek megoszlása a Széchenyi-hegyen talált védett növényfajok körében.

Fig. 3. Frequency distribution of floristic elements for the protected plants encountered on the Széchenyi Hill. (1) number of species, (2) sub-Mediterranean, (3) Ponto-Pannonian, (4) PontoMediterranean, (5) Balkan-Pannonian, (6) Pannonian endemism, (7) Central European - Mediterranean, (8) Eurasian continental, (9) southeastern European, (10) (Central) European.

\section{Köszönetnyilvánítás}

Ez úton mondunk köszönetet Csontos Péternek és Tamás Júliának, akik a Serratula radiata és a Sternbergia colchiciflora állományára felhívták a figyelmünket.

\section{Irodalomjegyzék}

BAjor Z. 2009: Budapest természeti kalauza. Kossuth Kiadó, Budapest, pp. 19-24.

Balogh L., Bathó B., Beregi l., Dedák D., Forintos N., Kiss A., Mihalik R., Nagy Sz., Péter N., Pörge Á., Rozgonyi Zs., Rusvai K., Stillling F., Szenek Z. 2016: A világ természetvédelmének története 1991 és 1995 között (védett területek alapítása). Tájökológiai Lapok 14(2): 99-115.

Bartha D., Király G., Schmidt D., Tiborcz V., Barina Z., Csiky J., Jakab G., Lesku B., SChmotzer A., Vidéki R., Vojt Kó A., Zólyomi Sz. (szerk.) 2015: Magyarország edényes növényfajainak elterjedési atlasza. Nyugat-magyarországi Egyetem Kiadó, Sopron, 329 pp.

Bognár F., Kálmán N., Kiss A., Krajcsovszky B., Luca V., Magyar V., Mák R., Morvai Gy. E., Ragó M., Rusvai K., Tóth N., Tóth T., Szilágyi Zs. 2016: A világ természetvédelmének története 1996 és 2000 között (védett területek alapítása). Tájökológiai Lapok 14(2): 191-205. 
BoRBÁs V. 1879: Budapestnek és környékének növényzete. Magyar Királyi Egyetemi Könyvnyomda, Budapest, $172 \mathrm{pp}$.

Centeri Cs., Szalai Z., Ja kab G., Barta K., Farsang A., Szabó Sz., Bíró Zs. 2015: Soil erodibility calculations based on different particle size distribution measurements. Hungarian Geographical Bulletin 64(1): 17-23. https://doi.org/10.15201/hungeobull.64.1.2

DövÉNYI Z. (szerk.) 2010: Magyarország kistájainak katasztere. MTA Földrajztudományi Kutatóintézet, Budapest, pp. 637-641.

Ellwanger G., Runge S., Wagner M., Ackermann W., Neukirchen M., Frederking W., MÜller C., Ssymank A., Sukopp U. 2018: Current status of habitat monitoring in the European Union according to Article 17 of the Habitats Directive, with an emphasis on habitat structure and functions and on Germany. Nature Conservation 29: 57-78. https://doi.org/10.3897/natureconservation.29.27273

Fekete G., KirÁly G., MolnÁr Zs. 2017: A Pannon vegetációrégió lehatárolása. Botanikai Közlemények 104(1): 85-108. https://doi.org/10.17716/botkozlem.2017.104.1.85

Havas G. (szerk.) 1976: Budapest földrajza az iskolai oktatásban. Tankönyvkiadó, Budapest, pp. $14-33$.

HEgEDÜs Á. 2002: Budapest jelenlegi virágos flórája. Animula Kiadó, Budapest, 68 pp.

Hou W., WALz U. 2016: An integrated approach for landscape contrast analysis with particular consideration of small habitats and ecotones. Nature Conservation 14: 25-39. https://doi.org/10.3897/natureconservation. 14.7010

Jancsovszka P. 2016: Fenntartható fejlődési célok. Tájökológiai Lapok 14(2): 171-181.

KIRÁLY G. (szerk.) 2009: Új magyar füvészkönyv. Magyarország hajtásos növényei. Határozókulcsok. Aggteleki Nemzeti Park Igazgatóság, Jósvafö, 616 pp.

Központi Statisztikai Hivatal: Népszámlálás 2011. Területi adatok - Budapest. http:// www.ksh.hu/nepszamlalas/tablak_teruleti_01 (utolsó letöltés: 2019. szeptember 23.)

Molnár Cs., Haszonits Gy., Malatinszky Á., Kovács G. K., Kovács G., NaGy T., Molnár V. A., TAKÁcs A. 2017: Pótlások Magyarország edényes növényfajainak elterjedési atlaszához III. Kitaibelia 22(1): 122-146. https://doi.org/10.17542/kit.22.122

MolnáR V. A. 2007: Adatok a Lathyrus pallescens (Bieb.) C. Koch 1841 ismeretéhez. Botanikai Közlemények 96(1-2): 57-65.

Möckel S. 2017: The European ecological network "Natura 2000" and its derogation procedure to ensure compatibility with competing public interests. Nature Conservation 23: 87-116. https://doi.org/10.3897/natureconservation.23.13603

Nagy K. M., Malatinszky Á. 2019: Unique botanical values in a metropolitan area and the landscape history reasons of their occurrence on the Széchenyi Hill, Budapest. Nature Conservation 32: 35-50. https://doi.org/10.3897/natureconservation.32.30807

Pechanec V., Machar I., Pohanka T., Opršal Z., Petrovič F., Švajda J., Šálek L., Сhobot K., Filippovová J., Cudlín P., MÁlková J. 2018: Effectiveness of Natura 2000 system for habitat types protection: A case study from the Czech Republic. Nature Conservation 24: 21-41. https://doi.org/10.3897/natureconservation.24.21608

PÉNZEs A. 1942: Budapest élővilága. Királyi Magyar Természettudományi Társulat, Budapest, $236 \mathrm{pp}$.

PÉNZEs A. 1956: Budapest élővilága. Társadalom- és Természettudományi Ismeretterjesztő Társulat, Budapest, $137 \mathrm{pp}$.

Simon T., Horánszky A., Dobolyi K., Szerdahelyi T., Horváth F. 2000: A magyar edényes flóra értékelő táblázata. In: Sımon T.: A magyarországi edényes flóra határozója. Tankönyvkiadó, Budapest, pp. 837-955. 
SomLyay L. 2009: A Budai-hegység florisztikai növényföldrajzának fő vonásai. Kitaibelia 14(1): $35-68$.

SomLYAY L. 2011: Adatok Budapest környéke flórájának ismeretéhez. Kitaibelia 15(1-2): 101-108.

SomLYAY L., MAKÁDi S., CsÁBI M. 2016: Adatok Budapest környéke flórájának ismeretéhez II. Kitaibelia 21(1): 33-50. https://doi.org/10.17542/kit.21.33

Somlyay L., Pif Kó D. 2002: A Lathyrus pallescens (Bieb.) C. Koch Magyarországon, és más adatok a Budai-hegység flórájának ismeretéhez. Kitaibelia 7(2): 237-245.

Szollát Gy. 2006: Adatok a Szabadság-hegy félszáraz irtásrétjeinek flórájához. Kanitzia 14: 95-108. TAMÁs J., Vida G., Csontos P. 2017a: Contributions to the fern flora of Hungary with special attention to built walls. Botanikai Közlemények 104(2): 235-250.

https://doi.org/10.17716/BotKozlem.2017.104.2.235

TAMÁs J., Ösı Zs., Csontos P. 2017b: Egy kevéssé ismert vadhatás nyomában - szarvas kéreghántása Budakeszi körzetében. Tájökológiai Lapok 15(2): 115-120.

\section{A detailed survey of protected and adventive plant species on the Széchenyi Hill, Budapest}

\section{K. M. NAGY and Á. MALATINSZKY}

Szent István University, Institute of Nature Conservation and Landscape Management, H-2103 Gödöllő, Páter K. 1, Hungary; malatinszky.akos@mkk.szie.hu

Accepted: 2 September 2019

Key words: alien plants, Buda Hills, flora, protected plants, stand, slope steppe.

The Széchenyi Hill (Budapest, Hungary) is surrounded by urban areas and is frequented by visitors. The high nature conservation importance of the place and several factors threatening the site call for a thorough assessment of its flora. In our field survey, we found almost 12,000 stands of 33 protected and 1 strictly protected plant species with over 32,000 flowering shoots. Altogether, the sum of the legal values of the protected species exceeds 320,000 EUR. Pannonian-Pontic, eastern, and sub-Mediterranean floristic elements dominate among the protected species, providing evidence for a sub-Mediterranean climatic influence. 